\title{
Statyba
}

\section{BEAUTOKLAVIO PUTBETONIO ŠILUMINIŲ TECHNINIŲ SAVYBIŲ TYRIMAI}

\section{Gnip , V. Keršulis , A. Laukaitis , I. Gnip , V. Keršulis \& A. Laukaitis}

To cite this article: I. Gnip , V. Keršulis , A. Laukaitis , I. Gnip , V. Keršulis \& A. Laukaitis (1996) BEAUTOKLAVIO PUTBETONIO ŠILUMINIŲ TECHNINIŲ SAVYBIŲ TYRIMAI, Statyba, 2:8, 60-66, DOI: $10.1080 / 13921525.1996 .10590173$

To link to this article: https://doi.org/10.1080/13921525.1996.10590173

曲 Published online: 01 Nov 2012.

Submit your article to this journal

山 Article views: 50

7 Citing articles: 1 View citing articles 


\section{BEAUTOKLAVIO PUTBETONIO ŠILUMINIŲ TECHNINIŲ SAVYBIŲ TYRIMAI}

\section{I.Gnip, V.Keršulis, A.Laukaitis}

\section{Ivadas}

Dèl pastaruoju metu išaugusių kuro kainu gaminti autoklavinius akytbetonius darosi netikslinga, nes garas sudaro $40 \%$ savikainos. Todèl būty ekonomiškiau naudoti beautoklavị putbetonį.

Pustbetonis, kurio tankis mažesnis negu $600 \mathrm{~kg} / \mathrm{m}^{3}$, naudojamas atitvarose kaip šilumą izoliuojanti medžiaga, o didesnio tankio - ir laikančiosiose konstrukcijose. Galiojančiose statybinèse normose [1] šios medžiagos šiluminès - techninès charakteristikos nenurodytos, todèl atliekant konstrukcijy skaičiavimus naudojamasi akytbetonio atitinkamomis charakteristikomis, kurios del medžiagos sudeties ir gamybos technologinių ypatumų gali neatitikti faktinių.

Darbo tikslas - nustatyti juairaus tankio beautoklavio putbetonio šilumines technines savybes ir jas palyginti su [1] rodikliais.

\section{Tyrimo metodikos}

Tyrinèto natūraliomis sąlygomis kietėjančio 250 , 500 ir $800 \mathrm{~kg} / \mathrm{m}^{3}$ tankio putbetonio bandiniai pagaminti Termoizoliacijos instituto Vietinių rišančiuju medžiagu laboratorijoje. Aukščiau nurodyto tankio bandinių stipris gniuždant, išlaikius juos 28 paras, atitinkamai sudare $0.76,2.20$ ir $4.82 \mathrm{MPa}$.

Putbetonio šilumos laidumo koeficientus nustatinèjome pagal [2] metodiką esant vidutinei $25 \pm 0.3^{\circ} \mathrm{C}$ temperatūrai. Bandinių matmenys $250 \times 250 \times 50 \mathrm{~mm}$.

Putbetonio specifinè šiluma nustatyta Vilniaus technikos universitete (VTU) laikantis [3] reikalavimu. Laidumą vandens garams radome pagal [4] metodiką naudodami bandinius-cilindrus, kuriy skersmuo ir aukštis $100 \times 30 \mathrm{~mm}$, tankis 360,590 ir $780 \mathrm{~kg} / \mathrm{m}^{3} .240$, 630 ir $840 \mathrm{~kg} / \mathrm{m}^{3}$ tankio bandinių sorbcini drègni nustatėme pagal [5] metodiką.

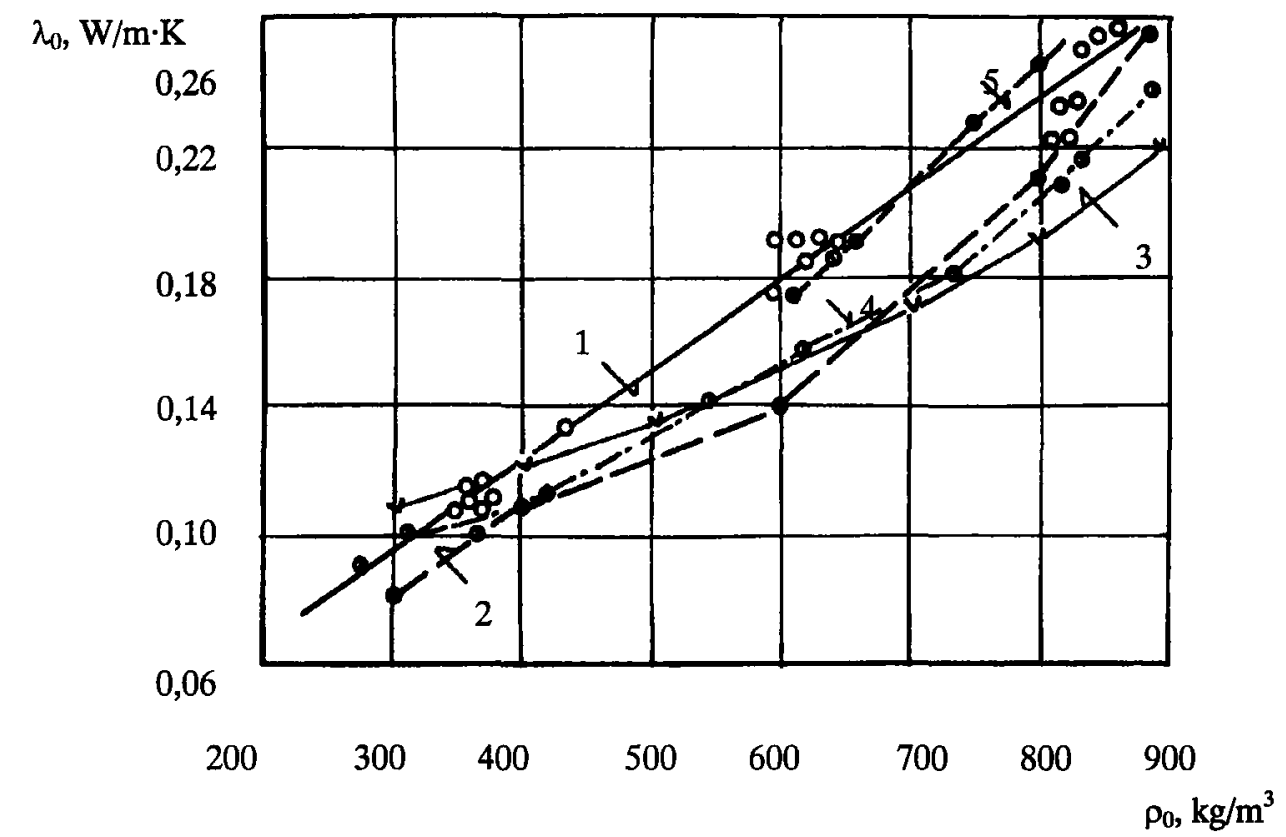

1 pav. Sauso putbetonio šilumos laidumo koeficiento priklausomybè nuo tankio: 1 - pagal Termoizoliacijos institute atliktus matavimus; 2 - pagal [1]; 3 - [7]; 4 - [8]; 5 - [9]

Fig. 1 Dry foam concrete thermal conductivity dependency on its density: 1 - according to Institute Termoizoliacija measurements; 2 - according to [1]; 3 - [7]; 4 - [8]; 5 - [9] 


\section{Putbetonio šilumos laidumo koeficientas}

Bandymais sužinota sauso putbetonio šilumos laidumo koeficiento priklausomybè nuo tankio pateikta 1 pav.

Matematiniais - statistiniais metodais [6] apdorojus dvidešimties bandymų rezultatus, gauta putbetonio šilumos laidumo koeficiento priklausomybès nuo tankio regresinè lygtis su koreliacijos koeficientu 0.988:

$$
\overline{\lambda_{0}}=0.0111+0.000278 \cdot p_{0},
$$

čia $\overline{\lambda_{0}}$ - sauso putbetonio šilumos laidumo koeficientas, W/mK; $\rho_{0}$ - sauso putbetonio tankis, $\mathrm{kg} / \mathrm{m}^{3}$.

Vidutinis kvadratinis eksperimentiniu duomenų nuokrypis nuo skaičiuojamuju reikšmiu yra 0.045 , o ribinè paklaida, prièmus tikimybę 0.95 , yra 0.078 .

Atlikta analizė rodo, kad putbetonio šilumos laidumo koeficiento didejimas yra tiesiog proporcingas jo tankio didejimui.
$\Delta \lambda_{w_{s}} \cdot 10^{2}, \Delta \lambda_{w_{t}} \cdot 10^{2}$ - vidutinis absoliutus šilumos laidumo koeficiento prieaugis $1 \%$ medžiagos drègnio pagal masę ir pagal tūrị, W/mK; $\delta_{w_{s}}, \delta_{w_{t}}$ vidutinis procentinis šilumos laidumo koeficiento prieaugis padidèjus drégniui $1 \%$ pagal masę ir pagal tūrị, \%.

1 pav., šalia eksperimenty duomenu (1 linija), pateiktos šilumos laidumo koeficiento reikšmès iš literatūros šaltinių [1, 7-10]. Reikia pažymèti, kad putbetonio šilumos laidumo koeficiento reikšmès, gautos bandymy metu, esant putbetonio tankiui nuo 300 iki $800 \mathrm{~kg} / \mathrm{m}^{3}$, viršija šio koeficiento reikšmes, pateiktas [1], vidutiniškai $14.2 \%$ (palyginti 1 ir 2 linijas). Atskiruose putbetonio tankio intervaluose, kaip $300 \div 400 \mathrm{~kg} / \mathrm{m}^{3}$ ir $600 \div 800 \mathrm{~kg} / \mathrm{m}^{3}$, skirtumas tarp bandymų metu gautu rezultatų ir literatūros šaltiniuose $[1,7,9]$ pateikiamų, nèra esminis.

1 lentelè. Putbetonio šilumos laidumo koeficiento priklausomybès nuo drègnio statistinès analizès rezultatai

Table 1. Foam concrete thermal conductivity dependency on its humidity data statistical analysis results

\begin{tabular}{|c|c|c|c|c|c|c|}
\hline $\begin{array}{l}\text { Statistikos } \\
\text { rodikliai }\end{array}$ & $\begin{array}{c}\Delta \lambda_{w_{s}} \cdot 10^{2} \\
\mathrm{~W} / \mathrm{m} \cdot \mathrm{K}\end{array}$ & $\delta_{w_{s}}, \%$ & $\begin{array}{c}\Delta \lambda_{w_{s}} \cdot 10^{2}, \\
W / \mathrm{m} \cdot \mathrm{K}\end{array}$ & $\delta_{w_{s}}, \%$ & $\begin{array}{c}\Delta \lambda_{w_{t}} \cdot 10^{2} \\
W / \mathrm{m} \cdot \mathrm{K}\end{array}$ & $\delta_{w_{t}}, \%$ \\
\hline 1 & 2 & 3 & 4 & 5 & 6 & 7 \\
\hline & \multicolumn{6}{|c|}{ Tankis nuo - $\mathrm{iki}, \mathrm{kg} / \mathrm{m}^{3}$} \\
\hline & \multicolumn{2}{|c|}{$370-600$} & \multicolumn{2}{|c|}{$620-870$} & \multicolumn{2}{|c|}{$370-870$} \\
\hline & \multicolumn{6}{|c|}{ Drègnis nuo - iki, \% pagal masę } \\
\hline & \multicolumn{2}{|c|}{$5.2-13.5$} & \multicolumn{2}{|c|}{$7.7-16.7$} & \multicolumn{2}{|c|}{$5.2-16.7$} \\
\hline $\begin{array}{l}\text { Bandymų } \\
\text { (nustatymų) } \\
\text { skaičius }\end{array}$ & 7 & 7 & 16 & 17 & 22 & 20 \\
\hline $\begin{array}{l}\text { Aritmetinis } \\
\text { reikšmės vidurkis }\end{array}$ & 0.258 & 1.61 & 0.534 & 2.44 & 0.690 & 3.38 \\
\hline $\begin{array}{l}\text { Empirinis } \\
\text { standartas }\end{array}$ & 0.049 & 0.22 & 0.093 & 0.37 & 0.117 & 0.63 \\
\hline $\begin{array}{l}\text { Variacijos } \\
\text { koeficientas, \% }\end{array}$ & 18.6 & 13.4 & 17.3 & 15.1 & 16.9 & 18.5 \\
\hline $\begin{array}{l}\text { Vidutinès } \\
\text { reikšmès galimas } \\
\text { minimalus dydis }\end{array}$ & 0.213 & 1.41 & 0.484 & 2.26 & 0.638 & 3.09 \\
\hline $\begin{array}{l}\text { Vidutinès } \\
\text { reikšmès galimas } \\
\text { maksimalus dydis }\end{array}$ & 0.303 & 1.81 & 0.583 & 2.63 & 0.742 & 3.67 \\
\hline
\end{tabular}


Tiriant drègmès ịtaką nustatyti šilumos laidumo koeficientai keičiant bandiniu tanki nuo 370 iki 870 $\mathrm{kg} / \mathrm{m}^{3}$ ir drégni nuo $5.2 \mathrm{iki} 16.7 \%$. Bandymu metu gauty duomeny matematinès-statistinès analizès rezultatai pateikti 1 lentelèje. Čia pateikti duomenys leidžia teigti, $\mathrm{kad}$ iki $600 \mathrm{~kg} / \mathrm{m}^{3}$ tankio putbetonio bandinių šilumos laidumo koeficiento prieaugio $1 \%$ medžiagos drégnio pagal masę vidutinis dydis yra mažesnis, negu putbetonio bandinių, kurių tankiș viršija $600 \mathrm{~kg} / \mathrm{m}^{3}$.

Putbetonio bandinių vidutinis šilumos laidumo koeficiento prieaugis $1 \%$ medžiagos drégnio pagal tūrị visame tankio intervale yra praktiškai vienodas (1 lentelè). Tai paaiškinama tuo, kad tūrinis drègnis yra pastovesnis rodiklis, o svorinis drègnis labiau priklauso nuo medžiagos masès.

Remiantis atliktais bandymais galima tvirtinti, kad tarp putbetonio šilumos laidumo koeficiento ir drègnio yra linijinè priklausomybe, tai yra vidutinis šilumos laidumo koeficiento prieaugis padidejus drègniui $1 \%$ pagal masę ir pagal tūrị nepriklauso nuo drègmès, jau esančios medžiagoje (atliktų bandymu metu gautu reikšmiu ribose).

\section{Specifinė šiluminẻ talpa}

Sauso putbetonio bandiniu specifinè šiluminè talpa esant $20 \div 25{ }^{\circ} \mathrm{C}$ temperatūrai yra: $245 \mathrm{~kg} / \mathrm{m}^{3}$ tankio putbetonio - $980 \pm 50 \mathrm{~J} / \mathrm{kg} \cdot \mathrm{K}$ ir $840 \mathrm{~kg} / \mathrm{m}^{3}$ tankio $-850 \pm 50 \mathrm{~J} / \mathrm{kg} \cdot \mathrm{K}$. Šios reikšmès yra artimos pateiktoms [1].

\section{Sorbcinis drégnis}

Atliekant sorbcinio drègnio tyrimus visiška putbetonio bandiniy masès stabilizacija pasiekta po 115 parų. Gauti rezultatai išreikšti grafiškai sorbcijos izotermomis (2 pav., 1 linija).

Iš 2 pav. matome, kad tarp sorbcinio drégnio, išreikšto masès procentais, ir putbetonio tankio nèra aiškios priklausomybès.

2 pav. 2 linija pavaizduotas ivairaus tankio putbetonio sorbcinis drégnis pagal [7], kurio reikšmès yra daug mažesnès už bandymais gautas reikšmes. Ypač tai akivaizdu esant santykiniam oro drègniui nuo 50 iki $100 \%$. Tai rodo, kad sorbcija putbetonyje nepasibaigia monomolekuliniame adsorbciniame sluoksnyje. Izotermoje šią stadiją atitinka išgaubtoji kreivès dalis. Bandymais gauta sorbcijos izoterma (1 linija) rodo staigu medžiagos drégnio didejjimą. Tai vyksta todèl, kad, be adsorbcijos, prasideda kapiliarinè kondensacija. Šios stadijos 2-oje sorbcijos izotermoje néra, reikia manyti, dèl nepakankamai ilgo eksperimento laiko [7]. Tą patvirtina ir [11] duomenys, kurie pavaizduoti 3 linija.

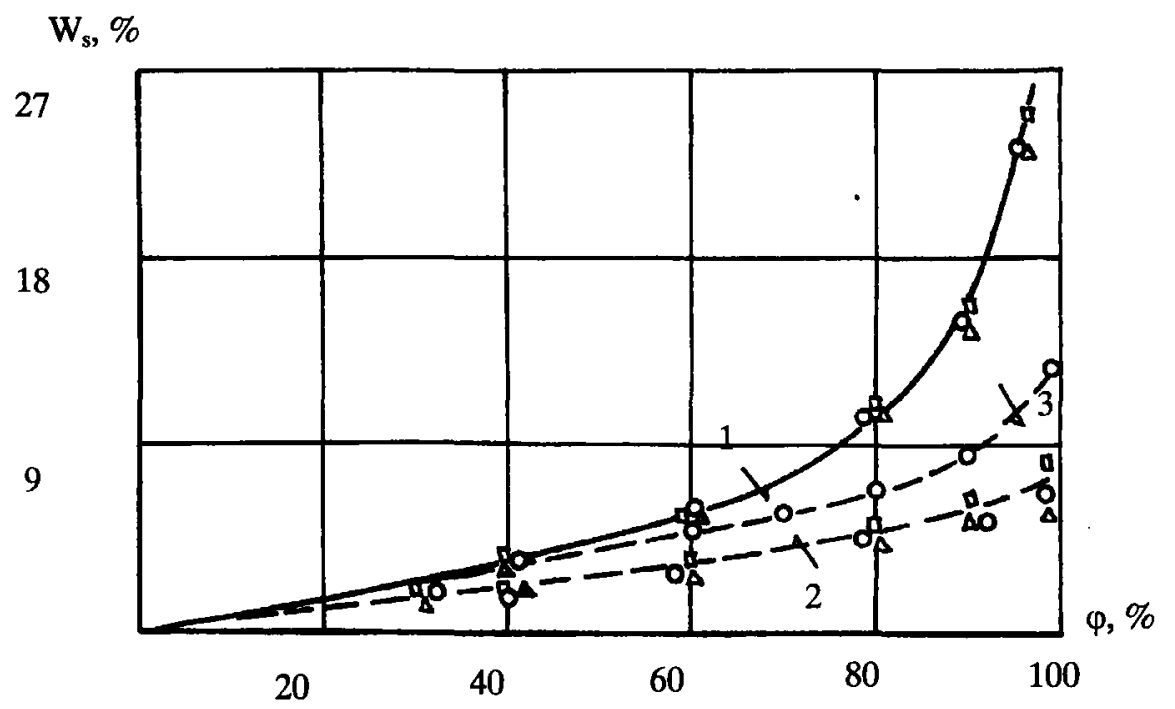

2 pav. Putbetonio sorbcinio drègnio $\left(W_{s}\right)$ priklausomybè nuo santykinio oro drègnio $(\varphi)$ : 1 - pagal Termoizoliacijos institute atliktus matavimus; 2 - pagal [7]; 3 - [11]. Putbetonio tankis, $\mathrm{kg} / \mathrm{m}^{3}:$ - 240; $\Delta-630 ; 0-840$

Fig. 2. Foam concrete sorption moisture $\left(W_{\mathrm{s}}\right)$ dependency on relative air humidity: 1 - according to Institute Termoizoliacija measurements; 2 - according to [7]; 3 - [11] Foam concrete density, $\mathrm{kg} / \mathrm{m}^{3}:-240 ; \Delta-630 ; 0-840$ 
Eksperimentiniai $240 \div 840 \mathrm{~kg} / \mathrm{m}^{3}$ tankio putbetonio sorbcinio drègnio vidutiniai dydžiai pateikti 2 lenteléje.

\section{Laidumas vandens garams}

Gauti putbetonio laidumo vandens garams nustatymo rezultatai pateikti 3 pav., iš kurio matome, kad šis rodiklis mažèja didejjant putbetonio tankiui.

Putbetonio laidumo vandens garams koeficiento priklausomybę nuo medžiagos tankio galima išreikšti regresine lygtimi su koreliacijos koeficientu (-0.984):

$$
\bar{\mu}=0.307-0.000257 \cdot \rho_{0},
$$

čia $\bar{\mu}$ - putbetonio laidumo vandens garams koeficientas, $\mathrm{mg} / \mathrm{m} \mathrm{h} \mathrm{Pa}$.

Vidutinis kvadratinis eksperimentiniu duomeny nuokrypis nuo skaičiuojamujų reikšmiu yra 0.04, o ribinè paklaida, prièmus tikimybę 0.95 , yra 0.073 .

3 pav., šalia bandymų metu gauty rezultatu (1 linija) pavaizduotos putbetonio laidumo vandens garams koeficiento reikšmès iš ivairių literatūros šaltinių $[1,7,10]$. Reikia pažymèti, kad putbetonio laidumo vandens garams koeficiento reikšmès, gautos bandymų metu, yra vidutiniškai apie $20 \%$ mažesnès už šio koeficiento reikšmes, pateiktas [1], naudojamas pastatų atitvarų drègminio režimo skaičiavimui.

2 lentelè. Putbetonio sorbcinis drègnis (\% pagal masę)

Table 2. Foam concrete sorption moisture (\% according to dry mass)

\begin{tabular}{|c|c|c|c|c|c|}
\hline \multirow{2}{*}{$\begin{array}{l}\text { Putbetonio tan- } \\
\text { kis nuo - iki, } \\
\mathrm{kg} / \mathrm{m}^{3}\end{array}$} & \multicolumn{5}{|c|}{ Santykinis oro drégnis, $\%$} \\
\hline & 40 & 60 & 80 & 90 & 97 \\
\hline $240-840$ & 3.4 & 5.6 & 10.7 & 15.0 & 23.7 \\
\hline
\end{tabular}

$\eta, \mathrm{mg} / \mathrm{m} \cdot \mathrm{h} \cdot \mathrm{Pa}$

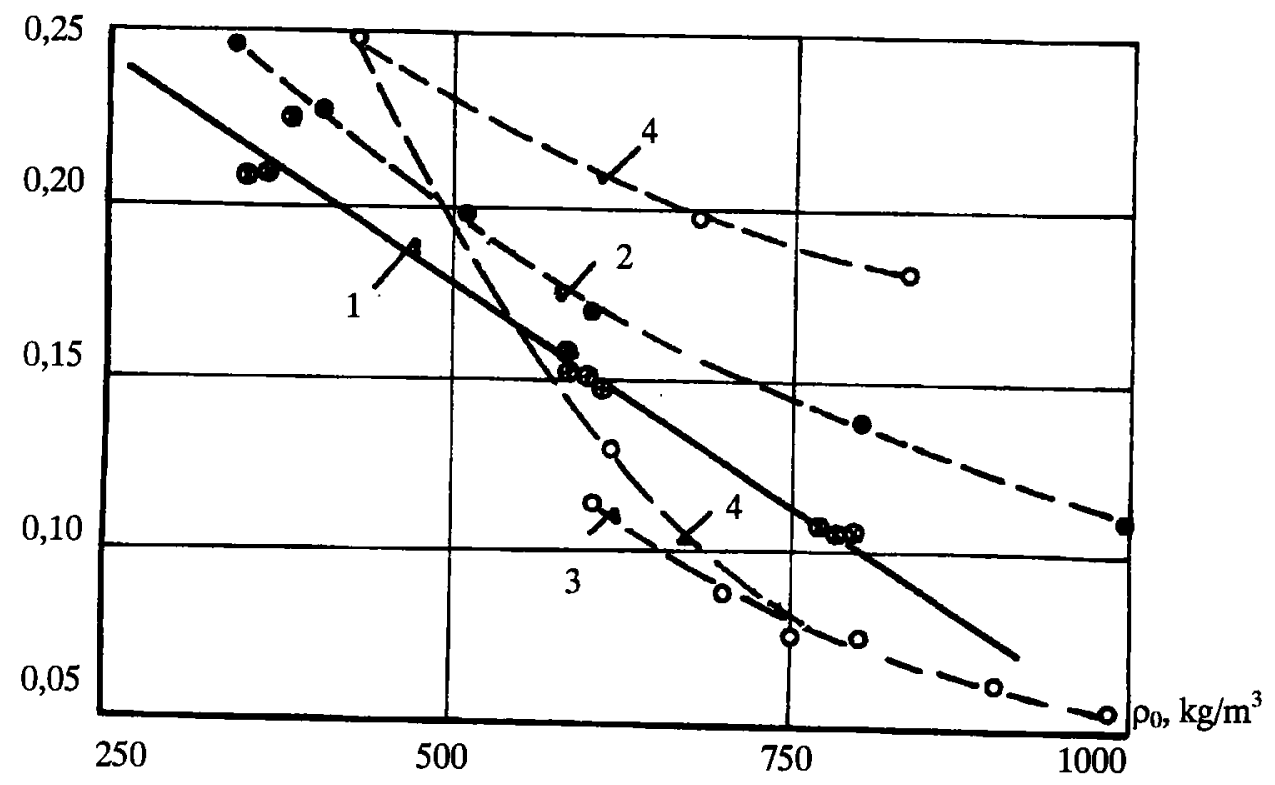

3 pav. Putbetonio laidumo vandens garams koeficiento priklausomybe nuo tankio:

1 - pagal Termoizoliacijos institute atliktus matavimus; 2 - pagal [1]; 3 - [10]; 4 - [7]

Fig. 3. Foam concrete water vapour permeability dependency on its density:

1 - according to Institute Termoizoliacija measurements; 2- according to [1]; 3 - [10]; 4 - [7] 


\section{Skaičiuojamieji šilumos laidumo ir šilumos imlumo} koeficientai

Skaičiuojamasis putbetonio šilumos laidumo koeficientas esant konkrečiam medžiagos tankiui ir parenkant skaičiuojamajji putbetonio drègni sudaro:

$$
\lambda\left(\rho_{0}, W_{s k}\right)=\overline{\lambda_{0}}\left(\rho_{0}\right) \cdot(I+\varepsilon)+\Delta \lambda_{w_{s}} \cdot W_{s k},
$$

čia $\Delta \lambda_{w_{s}}$ - imamas iš 1 lentelès pagal putbetonio tankį ir drégnị;

$W_{\text {sk }}$ - skaičiuojamasis putbetonio svorinis drègnis atitvarose, \% pagal masę;

$\varepsilon$ - ribinè paklaida 0.078 .

Skaičiuojant atitvary̨ drègminị režimą skaičiuojamasis putbetonio drégnis $\left(W_{\text {sk }}\right)$ pagal [11-13] parenkamas artimas putbetonio sorbciniam drègniui, esant santykiniam oro drégniui $80-85 \%$. Pagal bandymų metu gautus rezultatus (2 lentelè) ši reikšmé sudaro vidutiniškai $12 \%$ pagal masę.

Tuomet 250,500 ir $800 \mathrm{~kg} / \mathrm{m}^{3}$ tankio putbetonio skaičiuojamieji šilumos laidumo koeficientai yra atitinkamai $0.118,0.193$ ir $0.316 \mathrm{~W} / \mathrm{m} \cdot \mathrm{K}$.
Putbetonio šilumos imlumo koeficientas, esant temperatūros svyravimų periodui $\mathrm{z}=24 \mathrm{~h}$, skaičiuotas pagal [14] formulę:

$$
S_{z=24}=0.27 \cdot \sqrt{\rho_{w} \cdot C_{w} \cdot \lambda},
$$

čia $S_{z=24}$ - šilumos imlumo koeficientas, $\mathrm{W} / \mathrm{m}^{2} \mathrm{~K}$;

$\rho_{w}$ - drègno putbetonio tankis, $\mathrm{kg} / \mathrm{m}^{3}$, apskaičiuotas pagal

$$
\rho_{w}=\rho_{0}\left(1+0.01 \cdot W_{s k}\right)
$$

$\mathrm{C}_{\mathrm{w}}$ - drëgno putbetonio specifinè šiluma, $\mathrm{kJ} / \mathrm{kgK}$, apskaičiuota pagal

$$
C_{w}=\frac{C_{0}+0.01 \cdot W_{s k} \cdot C_{v}}{1+0.01 \cdot W_{s k}}
$$

čia $\mathrm{C}_{0}$ - sauso putbetonio specifinè šiluma, $\mathrm{kJ} / \mathrm{kgK}$;

$\mathrm{C}_{\mathrm{v}}$ - vandens specifinè šiluma, $\mathrm{kJ} / \mathrm{kgK}$.

Skaičiavimy rezultatai pateikti 3 lentelèje ( $24 \mathrm{~h}$

\begin{tabular}{|c|c|c|c|c|c|c|}
\hline \multicolumn{2}{|c|}{ Sauso putbetonio rodikliai } & \multirow{2}{*}{$\begin{array}{c}\mathrm{W}_{\mathrm{sk}}, \% \\
\text { pagal masę }\end{array}$} & \multicolumn{3}{|c|}{ Drégno putbetonio rodikliai } & \multirow{2}{*}{$\begin{array}{c}\mathrm{S}(24 \mathrm{~h} \\
\text { periodui), } \\
\mathrm{W} / \mathrm{m}^{2} \mathrm{~K}\end{array}$} \\
\hline$\rho_{0}, \mathrm{~kg} / \mathrm{m}^{3}$ & $\mathrm{C}_{0}, \mathrm{~kJ} / \mathrm{kgK}$ & & $\rho_{\mathrm{w}_{\mathrm{sk}}}, \mathrm{kg} / \mathrm{m}^{3}$ & $\begin{array}{l}\mathrm{C}_{\mathrm{w}_{\mathrm{sk}}}, \\
\mathrm{kJ} / \mathrm{kgK}\end{array}$ & $\lambda, \mathrm{W} / \mathrm{mK}$ & \\
\hline 250 & 0.98 & 12 & 280 & 1.324 & 0.118 & 1.786 \\
\hline 500 & 0.85 & 12 & 560 & 1.208 & 0.193 & 3.084 \\
\hline 800 & 0.85 & 12 & 896 & 1.208 & 0.316 & 4.992 \\
\hline
\end{tabular}
periodui).

3 lentelè. Skaičiuojamieji putbetonio šilumos imlumo koeficientai

Table 3. Foam concrete calculated heat capacity coefficients

\begin{tabular}{|c|c|c|c|c|c|c|c|}
\hline \multirow[t]{2}{*}{ Medžiaga } & \multicolumn{3}{|c|}{ Sausos medžiagos charakteristika } & \multirow[b]{2}{*}{$\begin{array}{c}\text { Skaičiuo- } \\
\text { jamasis } \\
\text { svorinis } \\
\text { drègnis } \\
\mathrm{W}_{\mathrm{sk}}, \%\end{array}$} & \multicolumn{3}{|c|}{ Skaičiuojamieji koeficientai } \\
\hline & $\begin{array}{c}\operatorname{tankis} \rho_{0} \\
\mathrm{~kg} / \mathrm{m}^{3}\end{array}$ & $\begin{array}{c}\text { šilumine } \\
\text { talpa } \mathrm{C}_{0} \\
\mathrm{~kJ} / \mathrm{kgK}\end{array}$ & $\begin{array}{c}\text { šilumos } \\
\text { laidumo } \\
\text { koeficien- } \\
\text { tas } \lambda_{0} \\
\mathrm{~W} / \mathrm{mK}\end{array}$ & & $\begin{array}{c}\text { šilumos } \\
\text { laidumo } \\
\text { koeficien- } \\
\text { tas } \lambda \text {, } \\
W / \mathrm{mK}\end{array}$ & $\begin{array}{c}\text { šilumos } \\
\text { imlumo } \\
\text { koeficientas S } \\
\text { (24 h periodui) } \\
\mathrm{W} / \mathrm{m}^{2} \mathrm{~K}\end{array}$ & $\begin{array}{c}\text { laidumas } \\
\text { vandens } \\
\text { garams } \mu \text {, } \\
\mathrm{mg} / \mathrm{m} \cdot \mathrm{h} \cdot \mathrm{Pa}\end{array}$ \\
\hline 1 & 2 & 3 & 4 & 5 & 6 & 7 & 8 \\
\hline \multirow{3}{*}{ Putbetonis } & 250 & $\frac{0.93}{-}$ & $\frac{0.08}{-}$ & $\underline{12}$ & $\frac{0.12}{-}$ & $\frac{1.79}{-}$ & $\frac{0.26}{-}$ \\
\hline & 500 & $\frac{0.85}{0.84}$ & $\frac{0.15}{0.13}$ & $\frac{12}{5}$ & $\frac{0.19}{0.17}$ & $\frac{3.08}{2.50}$ & $\frac{0.19}{0.20}$ \\
\hline & 800 & $\frac{0.85}{0.84}$ & $\frac{0.23}{0.21}$ & $\frac{12}{6}$ & $\frac{0.32}{0.29}$ & $\frac{4.99}{4.27}$ & $\frac{0.11}{0.14}$ \\
\hline
\end{tabular}

4 lentelè. Putbetonio šiluminiai techniniai rodikliai

Table 4. Foam concrete heat engineering values

Pastaba. Virš linijų - Termoizoliacijos instituto duomenys, žemiau linijų - pagal RSN 143-92. 


\section{Putbetonio šiluminiai techniniai rodikliai}

Eksperimentiniai ir skaičiuojamieji 250, 500 ir 800 $\mathrm{kg} / \mathrm{m}^{3}$ tankio beautoklavio putbetonio šiluminiai techniniai rodikliai pateikti 4 lentelèje, kur jie palyginti su [1] atitinkamais akytbetonių rodikliais.

\section{Išvados}

1. Sauso beautoklavio putbetonio šilumos laidumo koeficientas ir jo skaičiuojamasis dydis vidutiniškai $12 \%$ didesni už atitinkamus normuojamus akytbetoniu rodiklius.

2. Putbetonio laidumas vandens garams vidutiniškai $13 \%$ mažesnis negu akytbetonio.

3. Esant skaičiuojamajam putbetonio svoriniam drègniui du kartus didesniam už akytbetonio, putbetonio šilumos imlumo koeficientas vidutiniškai didesnis tik $20 \%$.

4. Skirtumai tarp putbetonio ir akytbetonio šiluminių techninių rodiklių yra ženklūs, todèl praktiniuose skaičiavimuose tikslinga naudotis konkrečiais beautoklavio putbetonio šiluminiais techniniais rodikliais.

5. $800 \mathrm{~kg} / \mathrm{m}^{3}$ tankio putbetonio šiluminiai techniniai rodikliai gali būti panaudoti projektuojant sienų apšiltinimo elementus (siliplastą ir pan.), o 250 ir $500 \mathrm{~kg} / \mathrm{m}^{3}$ tankio - parenkant atitvary šilumą izoliuojančio sluoksnio stori.

\section{Literatūra}

1. RSN 143-92. Pastatų atitvarų šiluminè technika. Vilnius, 1992. $71 \mathrm{p}$.

2. ГОСТ 7076-87. Материалы и изделия строительные. Метод определения теплопроводности. М.: Изд-во стандартов, $1987.12 \mathrm{c}$.

3. ГОСТ 23250-78. Материалы строительные. Метод определения удельной теплоемкости. М.: Изд-во стандартов, $1978.8 \mathrm{c}$

4. ГОСТ 25898-83. Материалы и изделия строительные. Метод определения сопротивления паропроницанию. М.: Изд-во стандартов, 1983.10 с.

5. ГОСТ 24816-81. Материалы строительные. Метод определения сорбционной влажности. М.: Изд-во стандартов, 1981.6 с.

6. С.А.Айвазян. Статистическое исследование зависимостей // Применение методов корреляционного и регрессионного анализов и обработка результатов эксперимента // М.: Металлургия, 1968. 228 с.

7. А.У.Франчук. Таблицы теплотехнических показателей строительньх материалов. М.: НИИстройфизики, 1969. 143 c.

8. Б.Н.Кауфман. Теплопроводность строительных материалов. М.: Стройиздат, 1955. 159 с.
9. П.И.Боженов, М.С.Сатин. Автоклавный пенобетон на основе отходов промышленности // Л.-М.: Стройиздат, 1960. $104 \mathrm{c}$.

10. А.Т.Баранов. Пенобетон и пеносиликат. М.: Промстройиздат, 1956. 82 с.

11. К.Ф.Фокин. Строительная теплотехника ограждающих частей зданий. М.: Стройиздат, 1973. $288 \mathrm{c}$.

12. Р.В.Щекин. Теплотехнические расчеты ограждающих конструкций отапливаемых зданий. Киев: Будивэльник, 1966. $113 \mathrm{c}$

13. И.С.Каммерер. Теплоизоляция в промышленности и строительстве / Пер. с нем. М.: Стройиздат, 1965. $378 \mathrm{c}$.

14. В.М.Ильинский. Строительная теплофизика // Ограждающие конструкции и микроклимат зданий. М.: Высшая школа, 1974. 320 с.

İteikta 19960620

\section{INVESTIGATION INTO NON-AUTOCLAVED FOAM CONCRETE HEAT ENGINEERING PROPERTIES}

\section{I.Gnip, V.Keršulis, A.Laukaitis}

\section{Su m m a ry}

The purpose of this investigation was to determine various density foam concrete heat engineering properties. These properties are not included in valid construction standards [1].

Thermal conductivity of samples was determined at $25^{\circ} \mathrm{C}$ according to [2], specific heat - [3], vapour permeability - [4] and sorption moisture - [5].

Dry foam concrete thermal conductivity $(\mathrm{W} / \mathrm{m} \cdot \mathrm{K})$ dependency on its density is given in Fig. 1 as well as after mathematical statistical treatment using the regressive equation [1].

Foam concrete thermal conductivity dependency on its humidity statistical analysis results is given in Table 1 , here $\Delta \lambda_{\mathrm{w}_{\mathrm{s}}}$ and $\Delta \lambda_{\mathrm{w}_{\mathrm{i}}}$ is the average absolute thermal conductivity increase for $1 \%$ materials moisture according to mass and volume, while $\delta_{\mathrm{w}_{\mathrm{s}}}$ and $\delta_{\mathrm{w}_{\mathrm{t}}}$ is the same increase, but in percentage value. Foam concrete thermal conductivity dependency on moisture is linear.

The specific heat value for 245 and $840 \mathrm{~kg} / \mathrm{m}^{3}$ density foam concrete is $980 \pm 50$ and $850 \pm 50 \mathrm{~J} / \mathrm{kg} \cdot \mathrm{K}$ respectively.

The determined foam concrete sorption moisture is given in Fig. 2 and Table 2. The steep moisture increase at high ambient air humidity is defined by adsorption and the beginning of capillary condensation. This state is not noted in literature curve 2 [7] and evidently due to the short experimental interval.

The vapour permeability results for foam concrete are given in Fig. 3 and using the regressive equation (2). Our results are approximately $13 \%$ lower than those given for porous concrete [1].

The calculated thermal conductivity was determined using equation (3), assuming that the sorbtion moisture is equal to the relative air humidity (80-85)\% (Table 2$)$. Then 250,500 and $800 \mathrm{~kg} / \mathrm{m}^{3}$ density foam concrete $\lambda_{\left(\rho_{0}, \mathrm{w}_{\mathrm{sk}}\right)}$ is equal to $0,12,0,19$ and $0,32 \mathrm{~W} / \mathrm{m} \cdot \mathrm{K}$ respectively. 
The foam concrete heat capacity coefficients S, calculated according to formula (4) for temperature fluctuation period $\mathrm{z}=24 \mathrm{~h}$ and according to damp foam concrete density and specific heat are given in Table 3.

Experimental for 260,500 and $800 \mathrm{~kg} / \mathrm{m}^{3}$ density nonautoclaved foam concrete heat engineering values are given in Table 4. For comparison, the denominators (under the line) show the corresponding values for porous concrete given in [1]. It is purposive to use in practical calculation specific non-autoclaved foam concrete heat engineering values because these differences are substantial.

Ivan GNIP. Doctor (technical sciences). Head of Building Materials Employment Laboratory. Institute Termoizoliacija, 28 Linkmenų St, 2600 Vilnius, Lithuania.

A graduate of Kaunas Polytechnical Institute (Civil engineering faculty), 1963, civil engineer. Doctor's degree in 1992 (thesis about thermal insulation materials and products). Author of 55 papers, 6 inventions. Research interests: building thermal insulation materials and products.
Vladislovas KERŠULIS. Doctor (natural sciences). Senior researcher of Institute Termoizoliacija (Building Materials Employment Laboratory). 28 Linkmenu St, 2600 Vilnius, Lithuania.

A graduate of Moscow Mendeleyev Chemical Technology Institute (Engineering physical-chemical faculty), 1967, industrial engineer. Doctor's degree in 1970 (thesis analyzing radiation chemistry problems). Author of 64 papers, 8 inventions. Research interests: thermal insulation materials, their properties, technology and ecological aspects.

Antanas LAUKAITIS. Doctor (technical sciences). Director of Institute Termoizoliacija. 28 Linkmeny St, 2600 Vilnius, Lithuania.

A graduate of Kaunas Polytechnical Institute, 1967, industrial engineer (Chemical technology faculty). Doctor's degree in 1975 (thesis about porous concrete acoustical products). Author of 76 papers, 16 investions and 4 patents. Research interests: thermal insulating and acoustical products made of porous concrete and their technology; heat insulating and acoustical materials. 